\title{
PENERAPAN STRING MATCHING DENGAN ALGORITMA BOYER MOORE PADA APLIKASI FONT ITALIC UNTUK DETEKSI KATA ASING
}

\author{
Rohmat Indra Borman ${ }^{1)}$, Agus Pratama ${ }^{2)}$ \\ 1) Komputerisasi Akuntansi, STMIK Teknokrat \\ ${ }^{2)}$ Teknik Informatika, STMIK Teknokrat \\ Jl. H.ZA Pagaralam, No 9-11, Labuhanratu,Bandarlampung \\ Email : rohmat_indra@teknokrat.ac.id ${ }^{1)}$,aguspratama@gmail.com ${ }^{2)}$
}

\begin{abstract}
Abstrak
Dalam karya ilmiah penulisan untuk kata asing, seperti kata berbahasa inggris, berbahasa yunani dan bahasa lainya dibuat dengan memiringkan kata tersebut. Aplikasi pengolah kata yang biasanya digunakan adalah Microsoft Office Word. Untuk memiringkan kata asing pada Microsoft Office Word menggunakan salah satu tools yang ada di toolbar Microsoft Office Word yaitu italic. Algoritma boyer moore merupakan salah satu algoritma yang digunakan untuk melakukan pencocokan string (string matching). Algoritma ini merupakan jenis exact string matching algorithm yang melakukan pencocokan string secara tepat dengan susunan karakter dalam string yang dicocokkan memiliki jumlah maupun urutan karakter dalam string yang sama. Cara kerja algoritma ini adalah dengan melakukan pencocokan dari kanan ke kiri yaitu men-scan karakter pattern dari kanan ke kiri dimulai dari karakter paling kanan. Penerapan algoritma boyer moore pada aplikasi font italic, akan mencari seтиa kemungkinan kata asing di dalam dokumen microsoft office word dengan yang ada di database aplikasi untuk membuat otomatis tercetak miring.
\end{abstract}

Kata kunci: Aplikasi, font italic, katas asing, algoritma, string matching, boyer moore, exact string matching.

\section{Pendahuluan}

Dalam sebuah karya ilmiah banyak menggunakan katakata asing khususnya kata berbahasa inggris. Penulisan karya ilmiah tersebut biasanya menggunakan aplikasi pengolah kata diantaraya Microsoft Office Word. Pada Microsoft Office Word untuk membuat kata tercetak miring harus menggunakan tools yang ada di toolbar yaitu italic. Hal ini berakibat memperlambat waktu dalam penulisan jika harus mengubah satu per satu katakata berbahasa inggris tersebut menjadi cetak miring dan kemungkinan kata asing tersebut terlewatkan untuk membuat tercetak miring. Selain itu akan cukup melelahkan apabila penulis karya ilmiah tersebut harus berulang-ulang menemukan kesalahan penulisan kata berbahasa inggris. Untuk menyelesaikan masalah diatas dibutuhkan sebuah aplikasi yang berguna untuk mencetak miring sebuah kata berbahasa inggris secara otomatis. Beberapa algoritma dapat digunakan untuk mendeteksi kata bahasa inggris yang akan di cetak miring.

Algoritma boyer moore merupakan algoritma yang digunakan untuk melakukan pencocokan string. Algoritma ini merupakan jenis exact string matching algorithm yang merupakan pencocokan string secara tepat dengan susunan karakter dalam string yang dicocokkan memiliki jumlah maupun urutan karakter dalam string yang sama. Algoritma ini melakukan pencocokan dari kanan ke kiri yaitu men-scan karakter pattern dari kanan ke kiri dimulai dari karakter paling kanan.

\section{Pembahasan}

\subsection{String Matching}

Pencocokan string atau string matching merupakan bagian penting dari sebuah proses pencarian string (string searching) dalam sebuah dokumen (Saragih, 2013). Hasil dari pencarian sebuah string dalam dokumen tergantung dari teknik atau cara pencocokan string yang digunakan. Pencocokan string (string matching) secara garis besar dapat dibedakan menjadi dua yaitu sebagai berikut :

a. Exact string matching, merupakan pencocokan string secara tepat dengan susunan karakter dalam string yang dicocokkan memiliki jumlah maupun urutan karakter dalam string yang sama. Contoh : kata open akan menunjukkan kecocokan hanya dengan kata open.

b. Inexact string matching atau Fuzzy string matching, merupakan pencocokan string secara samar, maksudnya pencocokan string dimana string yang dicocokkan memiliki kemiripan dimana keduanya memiliki susunan karakter yang berbeda (mungkin jumlah atau urutannya) tetapi string-string tersebut memiliki kemiripan baik kemiripan tekstual/penulisan (approximate string matching) atau kemiripan ucapan (phonetic string matching)

\subsection{Algoritma Boyer Moore}

Ide utama dari algoritma boyer moore adalah dengan melakukan pencocokan dari paling kanan string yang dicari. Dengan menggunakan algoritma ini, secara ratarata proses pencarian akan lebih cepat dibandingkan dengan proses pencarian lainnya. Ide dibalik algoritma 
ini adalah bahwa dengan memulai pencocokkan karakter dari kanan, dan bukan dari kiri, maka akan lebih banyak informasi yang didapat (Efendi, 2012).

Algoritma boyer moore menggunakan metode pencocokan string dari kanan ke kiri yaitu men-scan karakter pattern dari kanan ke kiri dimulai dari karakter paling kanan. Algoritma Boyer Moore menggunakan dua fungsi shift yaitu good-suffix shift dan bad-character shift untuk mengambil langkah berikutnya setelah terjadi ketidakcocokan antara karakter pattern dan karakter teks yang dicocokkan.

\subsection{Cara Kerja Algoritma Boyer Moore}

Cara kerja dari algoritma Boyer Moore adalah sebagai berikut :

a) Menjalankan prosedur preBmBc dan preBmGs untuk mendapatkan inisialisasi.

1. Menjalankan prosedur preBmBc.

Fungsi dari prosedur ini adalah untuk menentukan berapa besar pergeseran yang dibutuhkan untuk mencapai karakter tertentu pada pattern dari karakter pattern terakhir/terkanan. Hasil dari prosedur preBmBc disimpan pada tabel $\mathrm{BmBc}$.

Contoh kasus :

Pattern : MANAMAN

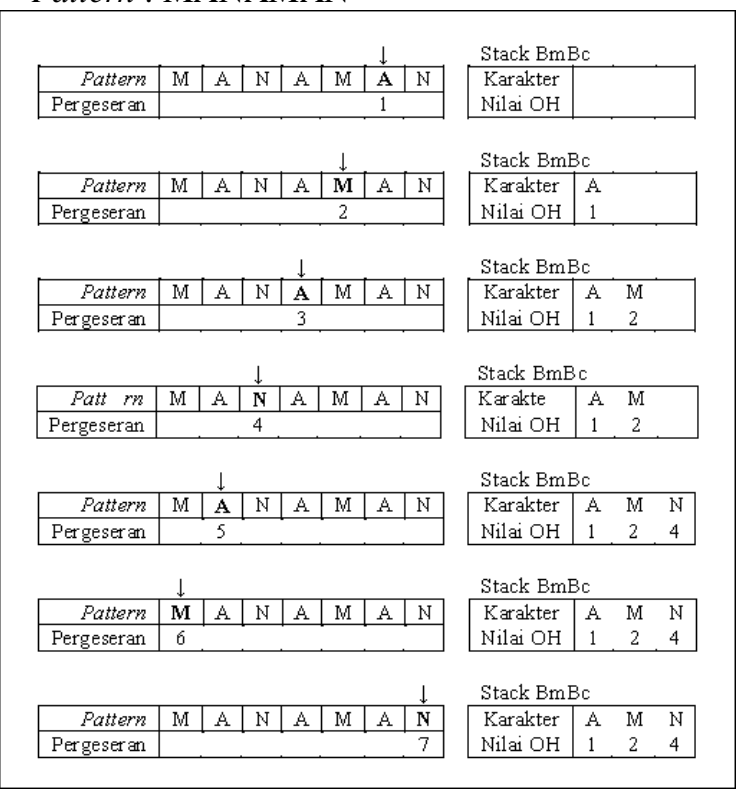

Gambar 1. Penyelesaian contoh kasus prosedur PreBmBc

2. Menjalankan prosedur preBmGs.

Sebelum menjalankan isi prosedur ini, prosedur suffix dijalankan terlebih dulu pada pattern. Fungsi dari prosedur suffix adalah memeriksa kecocokan sejumlah karakter yang dimulai dari karakter terakhir/terkanan dengan sejumlah karakter yang dimulai dari setiap karakter yang lebih kiri dari karakter terkanan tadi. Hasil dari prosedur suffix disimpan pada tabel suff. Jadi suff[i] mencatat panjang dari suffix yang cocok dengan segmen dari pattern yang diakhiri karakter ke-i.
Contoh kasus :

Pattern : MANAMAN

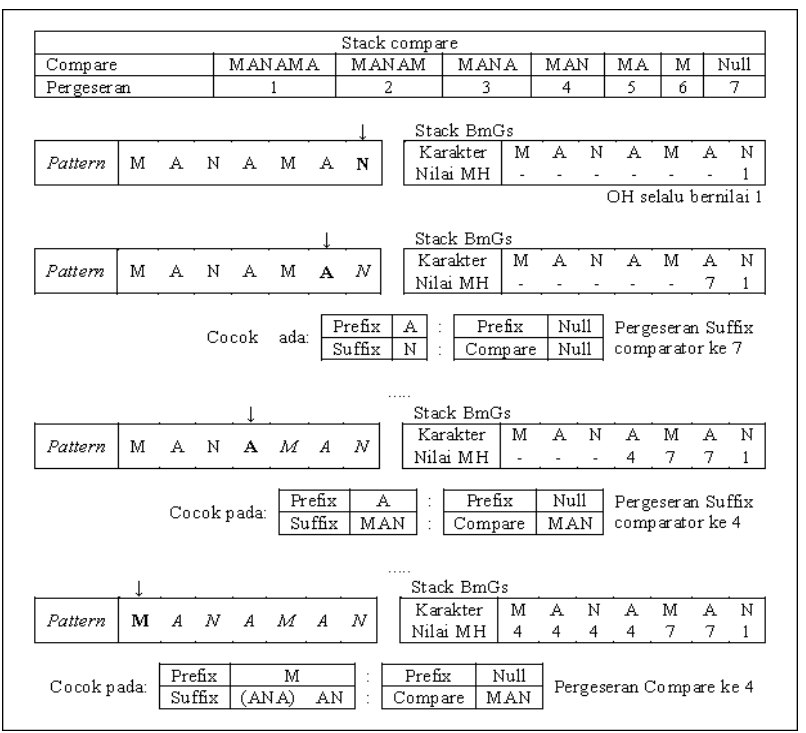

Gambar 2. Penyelesaian contoh kasus prosedur preBmGs

3. Dengan prosedur preBmGs, dapat diketahui berapa banyak langkah pada pattern dari sebeuah segmen ke segmen lain yang sama yang letaknya lebih kiri dengan karakter di sebelah kiri segmen yang berbeda. Prosedur preBmGs menggunakan tabel suff untuk mengetahui semua pasangan segmen yang sama.

b) Dilakukan proses pencarian string dengan menggunakan hasil dari prosedur preBmBc dan preBmGs yaitu tabel $\mathrm{BmBc}$ dan BmGs.

Contoh kasus :

Pattern : MANAMAN

Teks : NAMANANAMMANAMAN

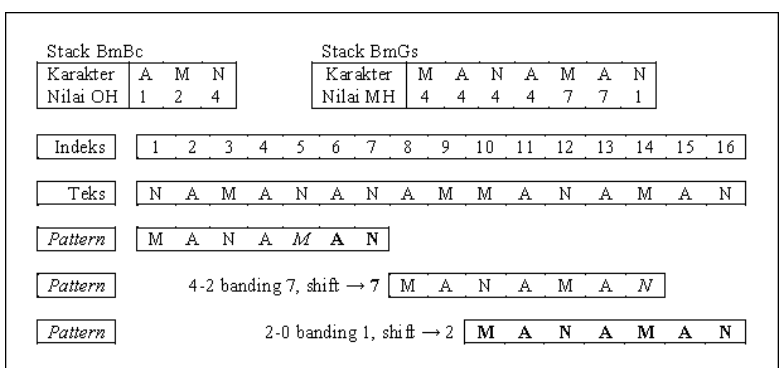

Gambar 3. Penyelesaian contoh kasus prosedur BM

\subsection{Gambar Alur Sistem}

Berikut rancangan alur cara kerja sistem berupa flowchart yang digunakan oleh penulis dalam melakukan penelitian: 


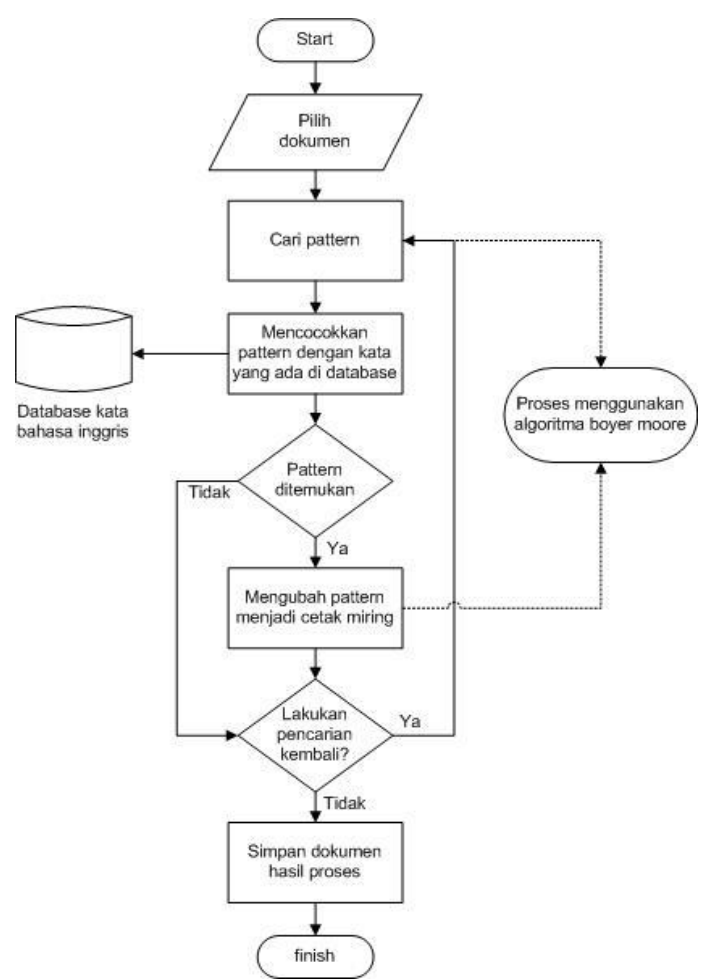

\section{Gambar 4. Flowchart Alur Sistem}

Dari flowchart diatas dapat dijelaskan dari awal proses penginputan dokumen, proses pencarian kata bahasa inggris didalam dokumen tersebut sampai dengan hasil cetak miring kata bahasa inggris yang kemudian disimpan menjadi sebuah dokumen baru tanpa mengubah dokumen aslinya.

\subsection{Cara Kerja Aplikasi dan Pengujian}

Setelah aplikasi dijalankan, maka akan tampil form uji dokumen yang berisi tombol cari dokumen, proses, simpan, keluar dan sebuah memo untuk menampilkan isi dokumen. Untuk menginputkan dokumen ke dalam aplikasi dapat menggunakan tombol cari dokumen, maka tampilan form nya adalah sebagai berikut :

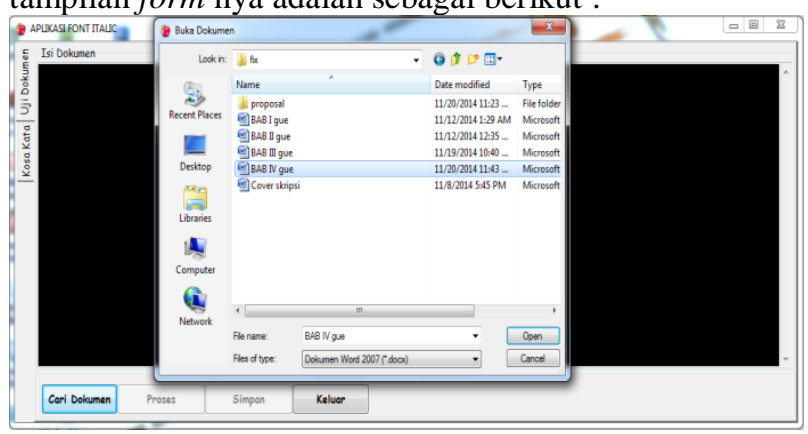

Gambar 5. Form cari dokumen

Setelah dokumen yang akan diproses diinputkan maka tampilan form setelah dokumen diinputkan adalah sebagai berikut :

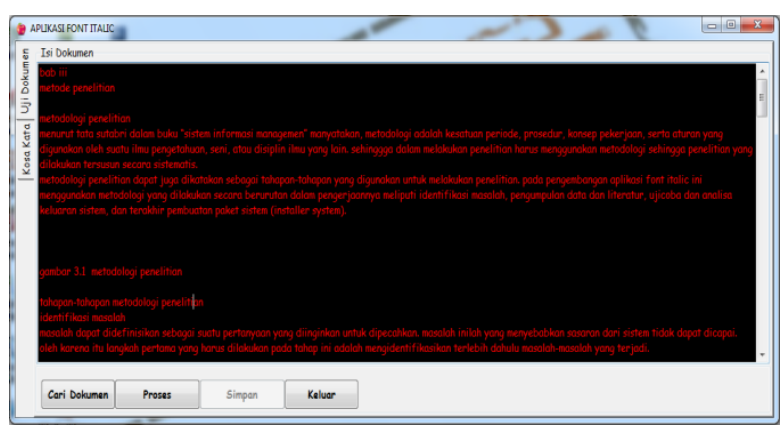

Gambar 6. Form buka dokumen

Ketika ditekan tombol proses maka aplikasi akan mulai pencarian kata. Tampilan form proses adalah sebagai berikut :

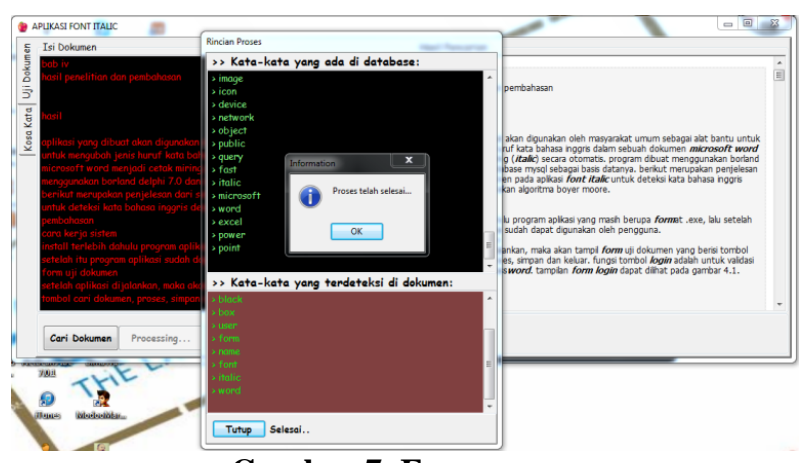

Gambar 7. Form proses

Dari proses tersebut yang dilakukan pertama kali adalah menjalankan prosedur preBmBc dan preBmGs untuk mendapatkan inisialisasi.

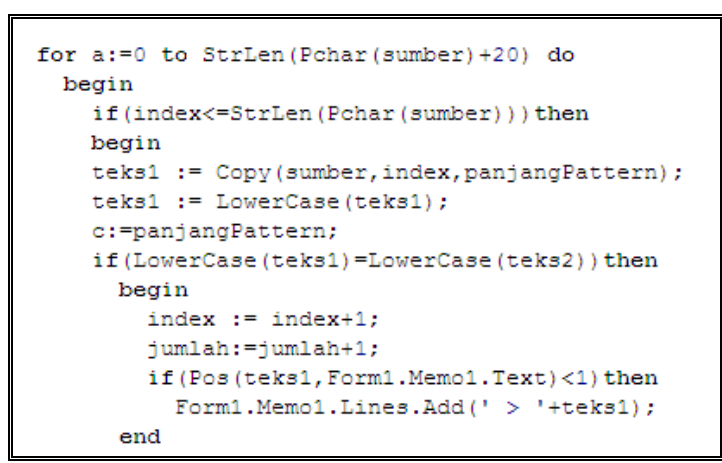

Gambar 8. Menentukan Pegeseran

Proses diatas untuk menentukan berapa besar pergeseran yang dibutuhkan untuk mencapai karakter tertentu pada pattern dari karakter pattern terakhir/terkanan. Kemudian dilakukan pencarian 


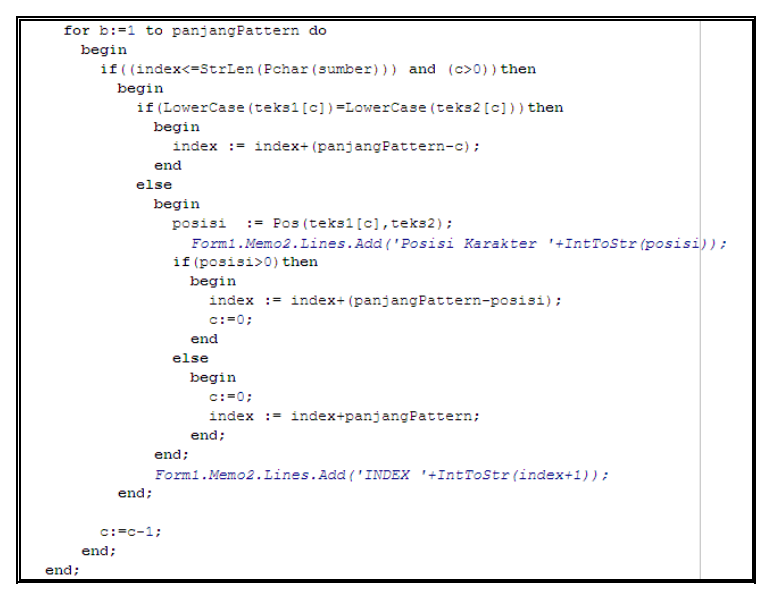

Gambar 9. Memeriksa Kecocokan Karakter

Setelah itu dilakukan pemeriksaan terhadap kecocokan sejumlah karakter yang dimulai dari karakter terakhir/terkanan dengan sejumlah karakter yang dimulai dari setiap karakter yang lebih kiri dari karakter terkanan tadi. Kemudian dilakukan pencarian terhadap hasil pencocokan.

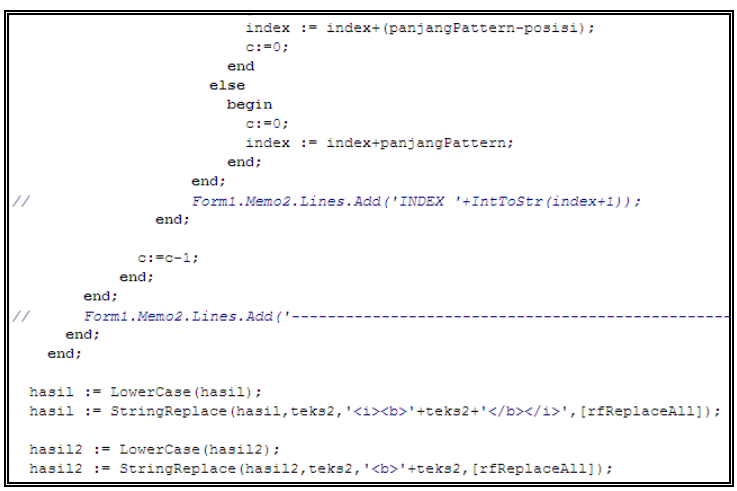

Gambar 10. Menentukan Hasil Pencocokan

Setelah proses pencarian selesai, maka akan didapatnya hasil proses. Tampilan form hasil proses pencarian adalah sebagai berikut :

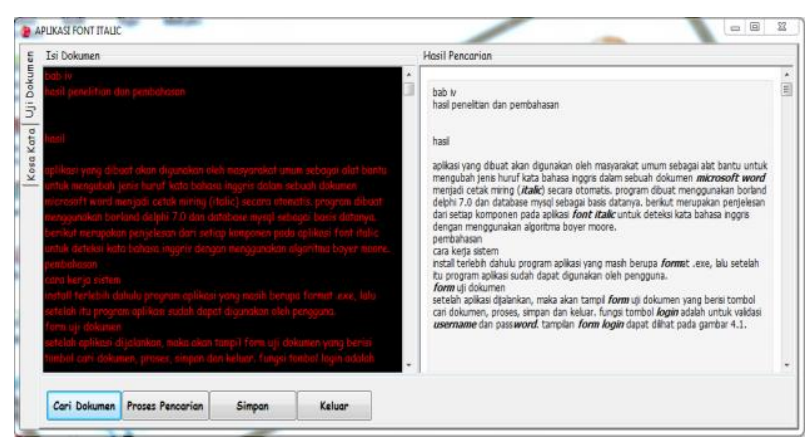

Gambar 11. Form hasil proses

Dari proses pencarian kata asing tersebut dilakukan pengujian proses per untuk deteksi kata asing dengan menerpakan algoritma boyer moore menghasilkan tabel berikut ini :
Tabel 1. Hasi Pengujian Pencocokan String

\begin{tabular}{|c|c|c|c|c|c|}
\hline $\begin{array}{c}\text { Halaman } \\
\text { (Lembar) }\end{array}$ & $\begin{array}{c}\text { Jumlah } \\
\text { Kata }\end{array}$ & $\begin{array}{c}\text { Ukuran } \\
\text { File }\end{array}$ & $\begin{array}{c}\text { Waktu } \\
\text { (Detik) }\end{array}$ & $\begin{array}{c}\text { Jumlah } \\
\text { kata } \\
\text { yang } \\
\text { tercetak } \\
\text { miring }\end{array}$ & $\begin{array}{c}\text { Jumlah } \\
\text { kata di } \\
\text { database }\end{array}$ \\
\hline 1 & 184 & $16 \mathrm{~Kb}$ & 2,23 & 17 & 125 \\
\hline 2 & 368 & $17 \mathrm{~Kb}$ & 4,48 & 34 & 125 \\
\hline 4 & 736 & $19 \mathrm{~Kb}$ & 11,94 & 68 & 125 \\
\hline 8 & 1472 & $22 \mathrm{~Kb}$ & 39,60 & 136 & 125 \\
\hline 16 & 2944 & $29 \mathrm{~Kb}$ & 151,86 & 272 & 125 \\
\hline 32 & 5888 & $42 \mathrm{~Kb}$ & 348,23 & 544 & 125 \\
\hline 64 & 11.776 & $63 \mathrm{~Kb}$ & 587,86 & 1088 & 125 \\
\hline
\end{tabular}

Setelah dilakukan proses deteksi kata asing dapat dilakukan penyimpanan file yang hasilnya berupa dokumen microsoft word yang baru.

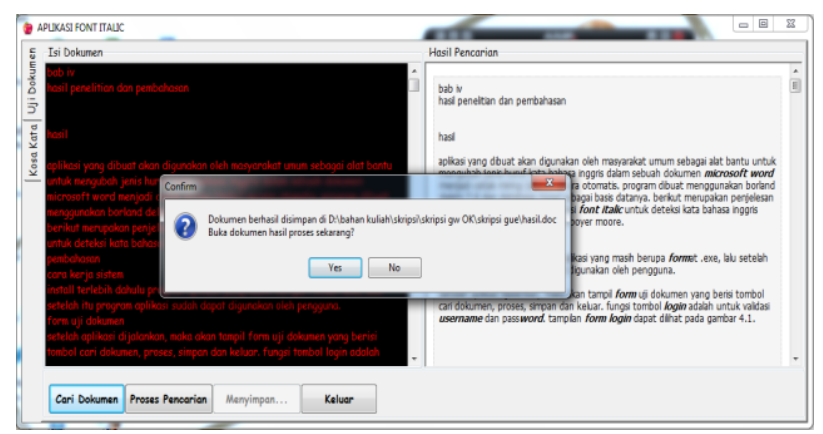

Gambar 12. Form simpan

Untuk menambah kata pada database pengguna dapat menambah kata bahasa inggiris pengguna system dapat menambahnya pada menu kosa kata :

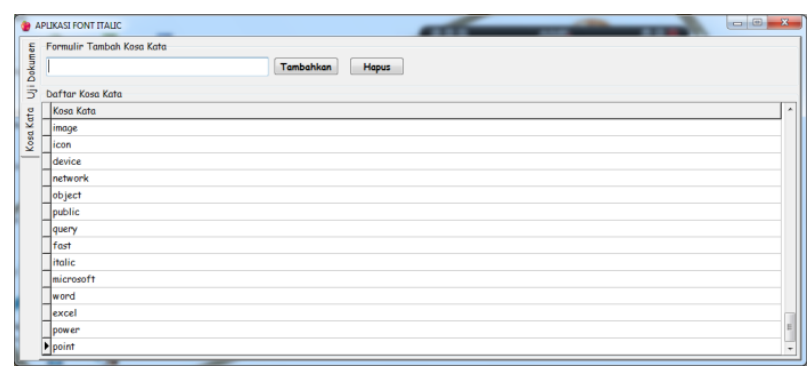

Gambar 13. Form kosa kata

\section{Kesimpulan}

Berdasarkan penelitian yang telah dilakukan dapat disimpulkan :

1. Algoritma boyer moore dapat digunakan sebagai pencocokan string untuk pencarian kata berbahasa inggris dengan mencari kata yang sama dalam database melalui proses pencocokan dari kanan ke 
kiri yaitu men-scan karakter pattern dari kanan ke kiri dimulai dari karakter paling kanan.

2. Pencocokan kata berbahasa inggris dapat diterapkan pada pengolah kata Microsoft Office Word dan dapat disimpan melalui format Microsoft Office Word yang sama dengan kata berbahasa inggris yang sudah tercetak miring.

3. Berdasarkan hasil pengujian proses deteksi kata bahasa inggris dengan algorima boyer moore jumlah katasing yang terdeteksi sudah sesuai dengan kata yang ada dalam database, tetapi semakin banyak jumlah kata yang ada pada teks maka semakin bertambah waktu yang dibutuhkan dalam melakukan pencarian.

\section{Daftar Pustaka}

[1] Charras, Christian., Lecroq, Thierry., Handbook of Exact String-Matching Algotithms. Oxford Unifersity Press, 1997.

[2] Effendi, Diana., Kurnaedi, Andri. Pengembangan Algoritma Boyer Moore pada Translator Bahasa Pemrograman, FTIK, Universitas Komputer Indonesia, 2012.

[3] Minandar, Arie., Tanoto, Andri., Tanadi, Davis. Aplikasi Algoritma Pencarian String Boyer-Moore Pada Pencocokan DNA. Departemen Teknik Informatika, Institut Teknologi

[4] Sagita, Vina., Irmina, Maria. Studi Perbandingan Implementasi Algoritma Boyer-Moore, Turbo Boyer-Moore dan Tuned Boyer-Moore dalam Pencarian String. Jurusan Teknik Informatika, Universitas Multimedia Nusantara, Tangerang, 2013.

[5] Saragih, May Aprina. 2013. Implementasi Algoritma Brute Force dalam Pencocokan Teks Font Italic untuk Kata Berbahasa Inggris pada Dokumen Microsoft Word. Jurusan Teknik Informatika, STIMIK Budidarma Medan 